\title{
Trisomy 17
}

National Cancer Institute

\section{Source}

National Cancer Institute. Trisomy 17. NCI Thesaurus. Code C37865.

A chromosomal abnormality consisting of the presence of a third copy of chromosome 17 in somatic cells. 